\title{
Exploring automobile dependency of housing estate residents and kampung dwellers in suburban Bandung, Indonesia
}

Fenita INDRASARI, Research Institute for Housing and Human Settlements, Ministry of Public Works; Indonesia

Abstract

Housing and transportation has become a pair of factors when it comes to decision of buying a house for the middle-income. This particular group of society is unique as they are aspired to luxury yet with limited affordability, particularly in the developing countries such as Indonesia. In many cases, housing estates are built in the form similar to gated community. Built in the suburban when usually the new housing estates are located quite in far distance to facilities, the residents are forced to own private vehicle(s) to conduct their daily activities. This situation shows the tendency of automobile dependence (Newman \& Kenworthy, 1996; 1999). It has also been reflected in the vehicle ownership statistics figures and the notorious traffic congestion of Indonesian cities.

The middle-income housing and their gated community has not only impacted their own travel pattern but also the residents living in kampung adjacent to their housing estate. Kampung dwellers have also reflected the middle-income characteristics with their lifestyle and automobile dependence. It has become eminent in suburban Bandung where pockets of kampung are found to be hidden amidst the housing estates whilst cars are parked on the roadsides. This is problematic in terms of affordability where they cannot really afford to own a car or motorbike as well as to rent a parking space since they usually live in small houses at kampung.

To understand the above phenomenon, this paper tries to explore the extent of automobile dependency of the residents living at housing estate and its adjacent kampung at three locations. Data collected from questionnaires and group interviews are descriptively analysed. Results have shown that most residents travel in far distance to reach their job location but do not travel in far distance to conduct their shopping, studying, and exercise activities though some of them own a motorbike. The latter is due to the presence of mobile green grocers, warung, traditional markets, good quality schools, sport facilities and open spaces within walking distance to their houses.

However, these nearby facilities are regularly visited mostly because the residents can travel within shorter distance through access points made available for public use. These access points help to create a network of alleys and streets connecting kampung and these facilities through the housing estates. When these access points are restricted or non-existed, the travel pattern would differ as has been uttered by the kampung dwellers. In one of the cases, the following disconnections between the kampung alleys and streets of housing estates have made the kampung dwellers altered either the location or the transportation mode of their activities.

There are lessons to be learned from these travel patterns. Housing estate development shall always have access to the kampung that have existed and vice versa. Such spatial connections may contribute to a change of travel behaviour 
from automobile dependence to active travel. However, it should be kept in mind that these results may not be generally applicable to other places with different socio-economic and spatial characters. Further work in the field may be benefited from more cases and larger population sample.

\section{Keywords}

Gated, housing estate, kampung, travel

\section{Introduction}

Housing and transportation has become a pair of factors when it comes to decision of buying a house for the middle-income. This particular group of society is unique as they are aspired to luxury yet with limited affordability, particularly in the developing countries such as Indonesia. In many cases, housing estates are built in the form similar to gated community. Built in the suburban when usually the new housing estates are located quite in far distance to facilities, the residents are forced to own private vehicle(s) to conduct their daily activities. This situation shows the tendency of automobile dependence (Newman \& Kenworthy, 1996; 1999). It has also been reflected in the vehicle ownership statistics figures and the notorious traffic congestion of Indonesian cities. According to BPS (2018), the number of motorbike ownership in Indonesia has escalated from a little less than 20 million in 2002 to more than 105 million in 2016 and 113 million in 2017. According to the Tomtom traffic index, Jakarta has gained the seventh place in 2018 from the fourth place in 2017 for its notorious traffic congestion. Meanwhile based on the 2017 Inrix global traffic scorecard, Bandung is within the 'big 60 ' by having its roads congested for more than 45 hours a week.

While Jakarta's congestion rate have decreased according to the index, presumably due to constant improvement of its public transportation network, a similar positive trend cannot be seen in other Indonesian cities. Furthermore these traffic indexes reflect the city but do not reflect what happens at the neighbourhood level. This paper argues that, at the neighbourhood level, the middle-income housing and their gated community has not only impacted their own travel pattern but also the residents living in kampung adjacent to their housing estate. Kampung dwellers have also reflected the middle-income characteristics with their lifestyle and automobile dependence. It has become eminent in suburban Bandung where pockets of kampung are found to be hidden amidst the housing estates whilst cars are parked on the roadsides. This is problematic in terms of affordability where they cannot really afford to own a car or motorbike as well as to rent a parking space since they usually live in small houses at kampung.

\section{Literature review}

The impact of residential development to travel has received extensive attention in the past two decades particularly since it has mostly taken shape as gated communities with perimeter walls, gates and cul-de-sacs. Duany, Zyberk \& Speck (2000), for example, have argued that cul-de-sac which originally conceived as youth's great playground has in fact made kids dependent on some adult to drive them around and lose their independent mobility. It was possible since the residential area with cul-de-sac layout increase distance 
between uses that are already been segregated. Perimeter walls and gates or cluster is basically producing the effect similar to cul-de-sac's in which traffic accumulates at one point and access points are made limited or singular hence forcing everyone to overcome a lengthy distance to reach uses. They include private roads, which limit public access (Charmes, 2010; Grant \& Curran, 2007).

To cope with the further distance resulted by the disconnected street layout between the ones within the housing estates and the existing road network, people who resides in the adjacent settlement may also need to own private vehicles particularly if their access to a direct route is cut-off. As a result, automobile dependency would be higher if travel options are restricted as evidenced in Indonesia as well as other Asian developing cities (Barter, 2000; Bowen, 2006; Handy, 2002; Rosa, 2007).

In terms of walking, a particular radius catchment area that is within reach of reasonable walking distance is the parameter. The distance, usually a quarter mile or 800 meters, derived from the 10-20 minutes walking with medium speed (Hess et al., 1999; Southworth, 2005). This walking distance has been considered as universal parameter which aligns with the walking speed range of pedestrian behaviour from various culture (Mateo-Babiano \& leda, 2007). If distance between uses lies beyond the walking distance, it is more likely that people are driving their private vehicles and vice versa.

The effects of gated communities to travel, however, do not apply universally but are instead differentially distributed and dependent on lifestyle, household structure, and different capacities to overcome distance (Maher, 1994; Nicholls, Phelan, \& Maller, 2015). Whilst distance is the main factor, its association to time and cost follow at the second place. Other factors that influence one's travel decision are socio-economic and physical condition. For example, one's income may affect their travel options, whilst options are available, not all options are considered as viable due to their limited affordability. Connectivity to transit has also been sought to add travel option for increasing the possibility of less car use (Cervero \& Kockelman, 1997; Ewing \& Cervero, 2010; Hoehner et al., 2005; Khattak \& Rodriguez, 2005; Schwanen \& Mokhtarian, 2005; Rodriguez et al., 2006).

\section{Methods}

To understand the automobile dependency phenomenon as resulted by private roads and housing estate development, this paper tries to explore the extent of private motorised vehicle use by the residents living at housing estate as well as the kampung dwellers living at the adjacent area. There are three study cases, as seen in figure 1, in which all of them are located in suburban Bandung and built in the early 1990s. The first study case is KM, a housing estate surrounded by perimeter walls which has three guarded gates for entry and three pedestrian access points open during the day. $\mathrm{NH}$, the second case, has perimeter walls with only one guarded gate for entry. NH has two pedestrian access points which used to be open all day from Monday to Friday but then closed at all time since the middle of 2018. The third case, PC, is an open housing estate which does not have perimeter walls and guarded gates. Vehicles can enter PC from three ways while pedestrians can enter from anywhere possible since there is no perimeter wall surrounding the housing estate. 


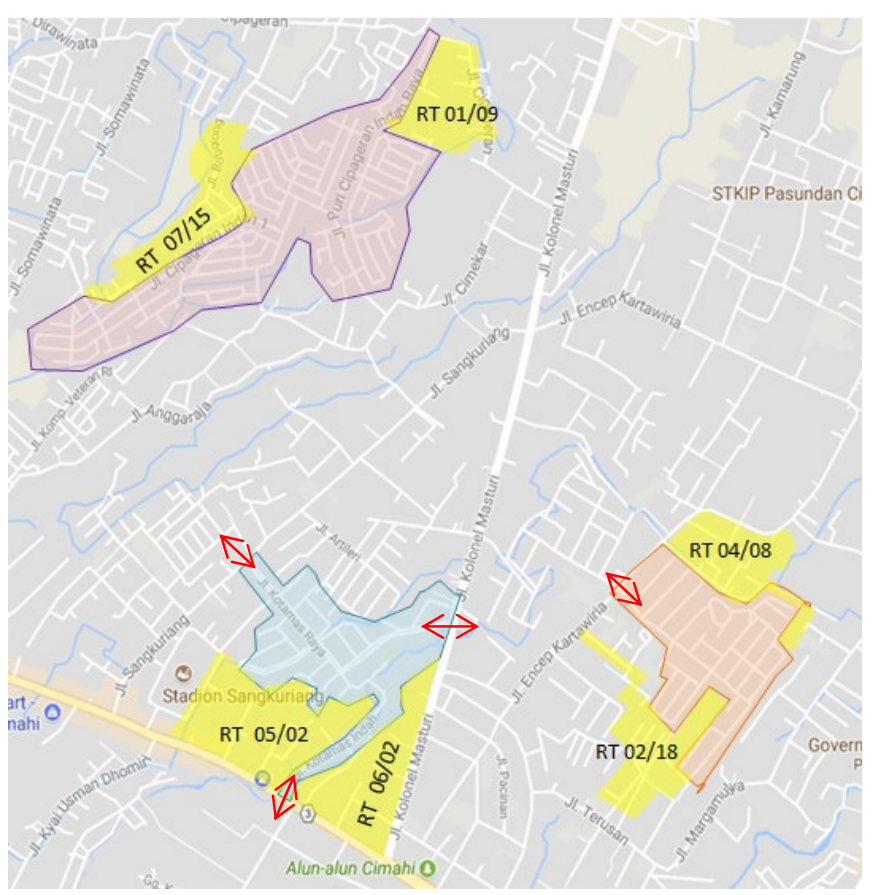

Figure 1 Location of study cases

(Bottom left-right: $\mathrm{KM}, \mathrm{NH}$; top: $\mathrm{PC}$ )

Data for this study comprised of mode of transportation, route and location of the activities to work, groceries shopping, study, and exercise. These data were collected using two different tools: questionnaires given to random housing estate residents and group interviews of the kampung dwellers. For the group interviews, participants are housewives who came to the session because of the neighbour leaders request. Prior to the group interview sessions, the author and team has come to visit the neighbour leader permission and cooperation. In discussing the analysis results, data from each group of participants are presented in separate in order to show the different pattern of mobility which may have been caused by the street network and access points as well as their associated socioeconomic status. A total of 136 people have provided the data described in this study. Other than the charts and pattern shown in maps, interview quotes from the kampung dwellers are provided to enrich the data as an explanation to the pattern.

\section{Results and Discussions}

In exploring the extent of private motorised vehicle use, result of data analysis is provided into five sub-sections according to each type of activity and ended with an overall discussion.

\subsection{Work}

From the total amount of participants, as provided in figure 2, thirty per cent either work at home or no longer work since their retirement. Meanwhile, majority of people drive their private motorised vehicles to work which located at a various distance from $5 \mathrm{~km}$ to $30 \mathrm{~km}$. Only a small percentage of participants who live in the kampung walk or ride angkot (one of the public transportation mode in Bandung) to work. None of the estate residents walk or 
ride angkot to work (see the bars coded with KM-r, NH-r and PC-r). Further explanations on the mode choice and routes taken are provided in the quotes and map in figure 3.

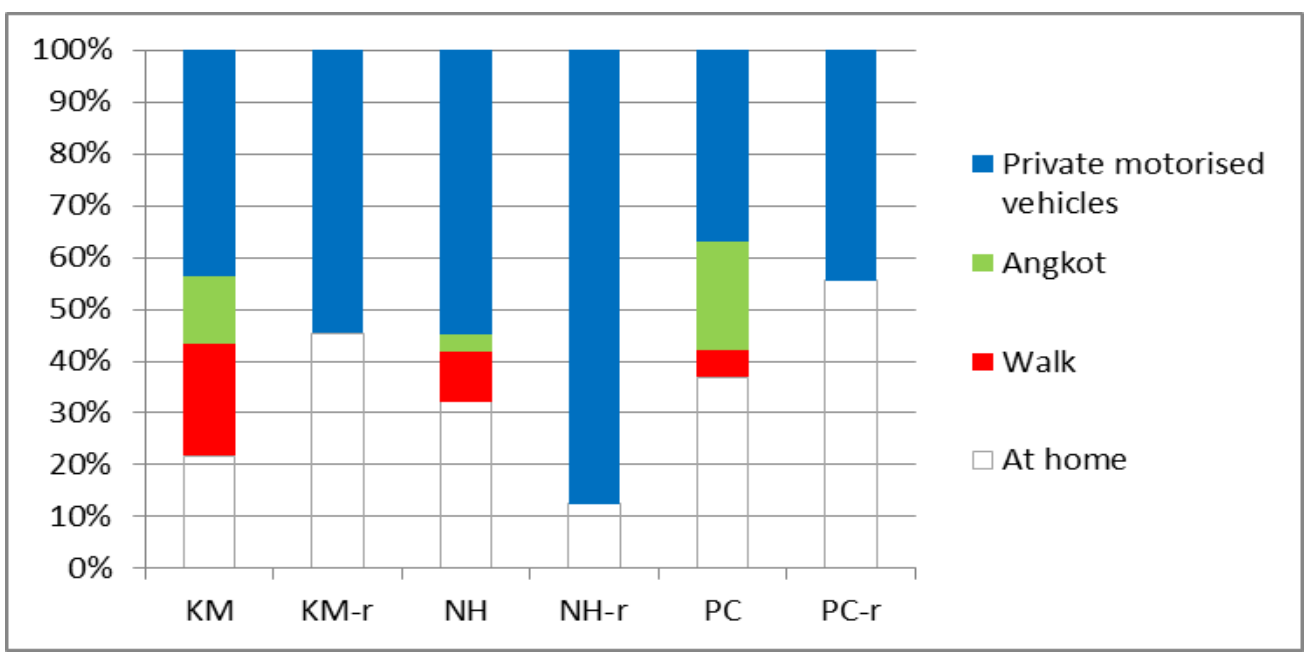

Figure 2 Mode of transportation to work

One participant who lives in the kampung adjacent to KM housing estate said that when her husband rides a motorbike from work, he mostly go through the kampung alley and rarely through the housing estate. The reason for not going through the housing estate is because of the guarded gate in which he has to ask the security guards every time he whishes to pass by as provided in the following quote:

"At night [he] goes through the north alley ... My husband usually comes home at 11 at night ... though the security guards also live in this kampung it would still be a bother to ask [them] only to open the gate in the middle of the night" (RKM)

To ride an angkot, the kampung dwellers who live adjacent to KM housing estate have to walk for $\mathbf{3 0 0}$ meters through the private roads within the estate, carry on through the other kampung alleys, before finally reach the public roads in which several angkot routes are served. Meanwhile the kampung dwellers who live adjacent to PC housing estate only need to walk for 50 meters to halt Cidahu route angkot.

Walking is only done by several participants whose workplace located within walking distance from their home, including who works as household servant at the housing estate as well as those who has a warung (stall) at home. It should be noted though that walking distance radius, as has been drawn as red circle in the map, is not the same as the real network distance that one has to go through. This is evidenced in one participant's experience who sells fresh fish and seafood at Pasar Atas, a traditional market located within 250 meters radius. Drawn as red line in the map, the usual route she takes to work is 350 meters long through the pedestrian access provided by the housing estate which leads to other kampung alleys. Should this access is shut, she would have to walk for 1200 meters and take three times longer (drawn as yellow line). She is fully aware of this condition as seen in the quote below:

"I work by selling fish at Pasar Atas every morning until 2 PM from 5 AM.

Sometimes I ride motorbikes but I mostly walk; me and my husband. Walking 
[route] is much nearer when the KM [housing estate pedestrian gate] is open. If it's closed, [I have to] walk further and take [more] time all the way to go out at the petrol station" (ISKM)

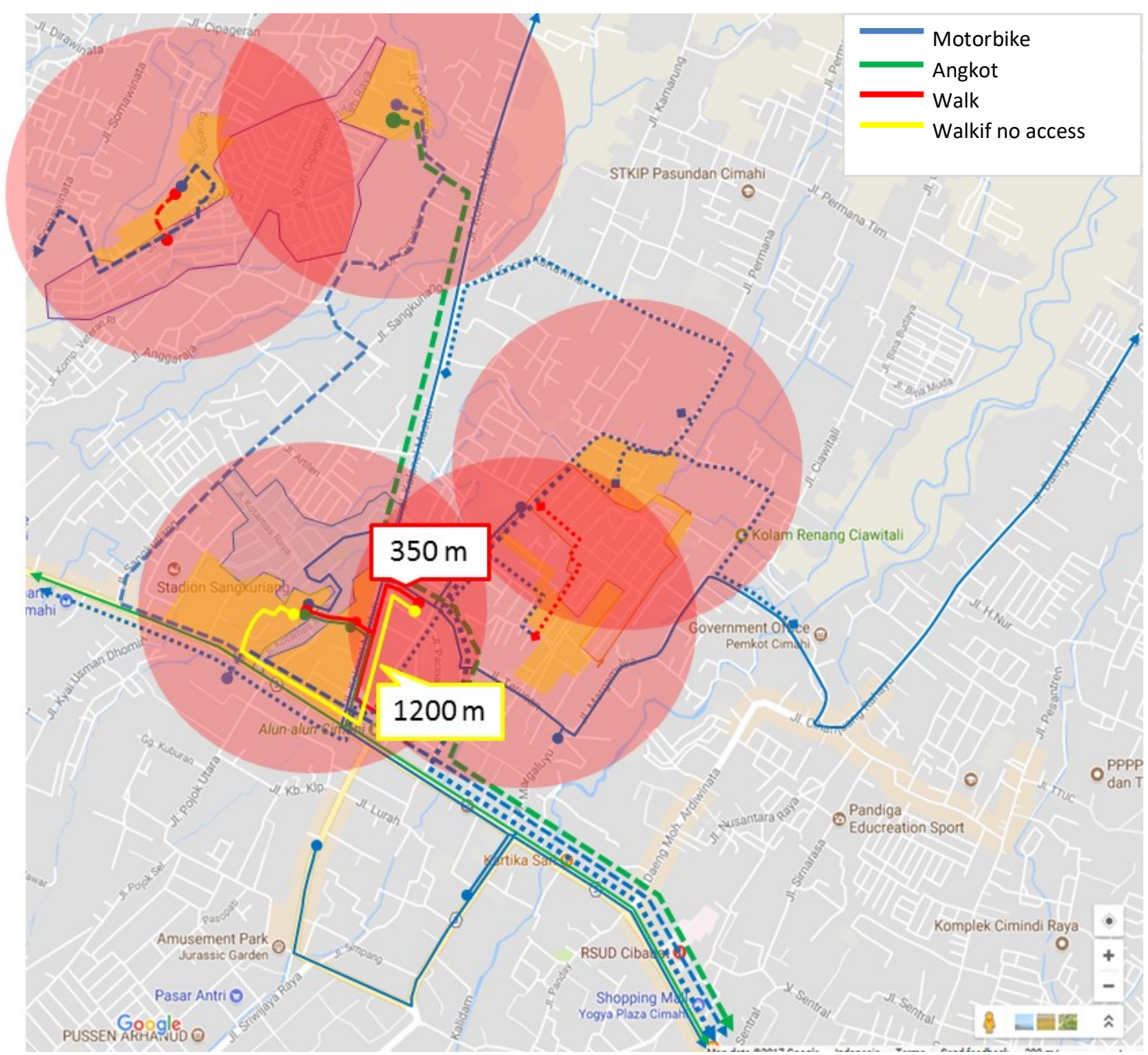

Figure 3 Route and mode of transport to work

On another case, there is a participant who used to work as a household helper at $\mathrm{NH}$ housing estate. She desbribed that the shut down of pedestrian access has become a factor in making a decision to resign from work. Not only her, the school children have also been affected by the access being shut. Though the kampung dwellers have complained, the access is still shut due to security reason. The quote below describes such conditions:

"When I used to work, I can still go through that door [pedestrian gate]. We cannot go through now. It becomes far since we have to go all the way to the front. That is why I stopped [working]. I pity the school children [since] they have to walk further. I had once being asked to be a representative of thiskampung dwellers to deliver our complaints to $\mathrm{NH}$ [housing estate residents]. They [NH 
residents] responded 'Go ahead [open the pedestrian gate] if you are willing to be responsible if there is any burglary here"' (INNH)

\subsection{Shopping}

For groceries shopping activities, the top graph in figure 4 shows that the majority of participants walk. However, there is a notable difference where the kampung dwellers mostly walk or ride angkot to buy groceries while the housing estate residents are divided between walk and riding their vehicles.

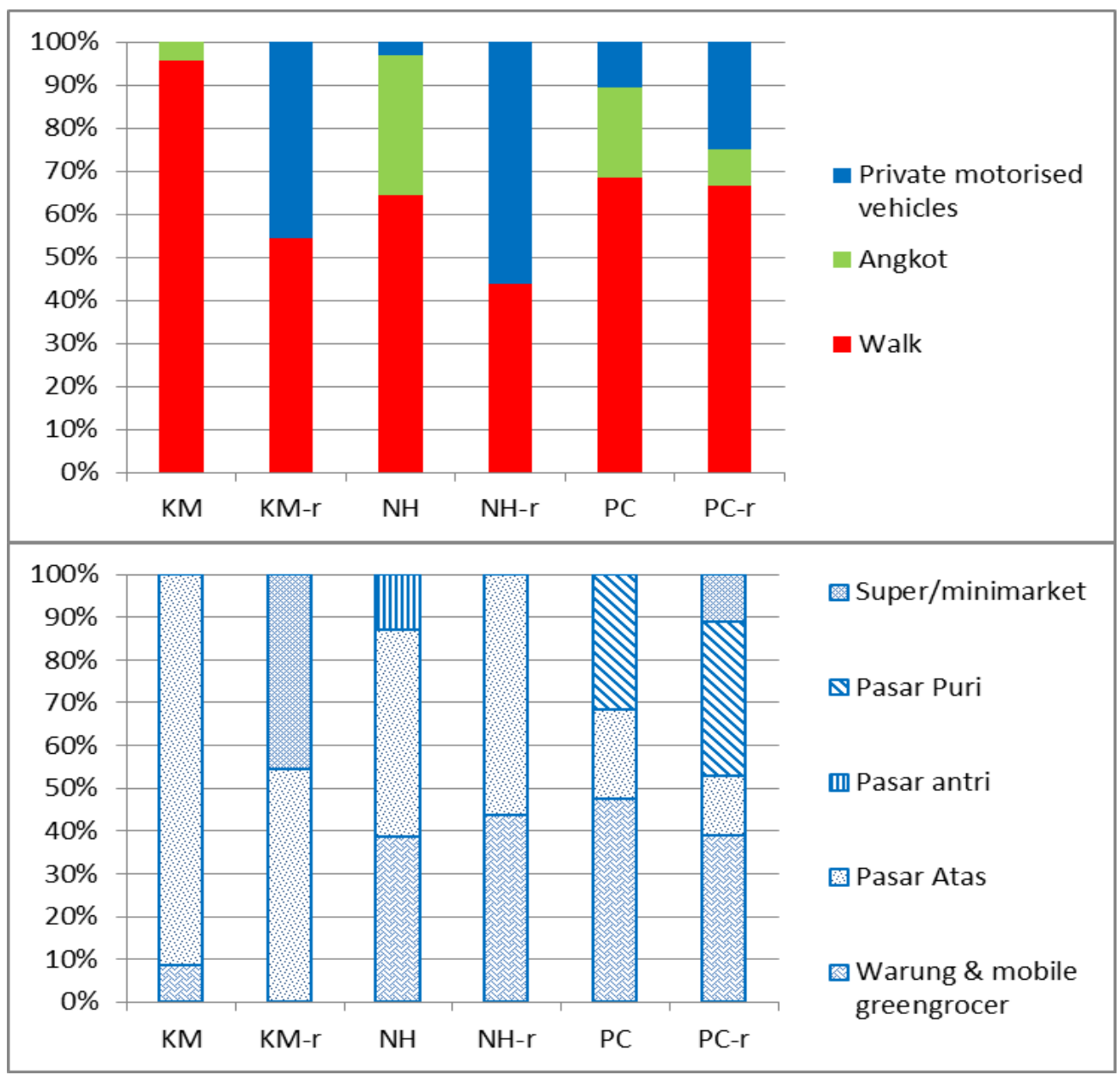

Figure 4 Mode of transportation and destination for shopping activities (Top-bottom: Mode of transportation, shopping destination)

The bottom graph in the same figure explains that the destination for groceries shopping makes the difference of such different mode of transportation. The kampung dwellers all go to either warung/mobile greengrocer or the traditional market which very easily accessible. On the other hand, estate residents who go to the traditional market are divided: KM estate residents walk to Pasar Atas located 300 meters away, $\mathrm{NH}$ estate residents ride their private vehicles to Pasar Atas located 600 meters away, and PC estate residents can walk to Pasar Puri, ride angkot to Pasar Atas ( $2 \mathrm{~km}$ away), or ride their private vehicles to Pasar Antri (5 km away). The locations of these traditional markets are provided in figure 5. Looking at the shopping destination of estate residents, only a small part of residents go to supermarket: 
nearly 50per cent of KM residents and 10 per cent of PC residents. The supermarket which the participants go to differ based on the distance to their houses starting from the nearby minimarket to the big supermarket within less than $5 \mathrm{~km}$ away. PC estate residents go to the west while $\mathrm{KM}$ and $\mathrm{NH}$ go to the east. While these residents shop once a week to once a month, the rest who shop at warung, mobile greengrocer and traditional market buy groceries in every two days or a few times a week.

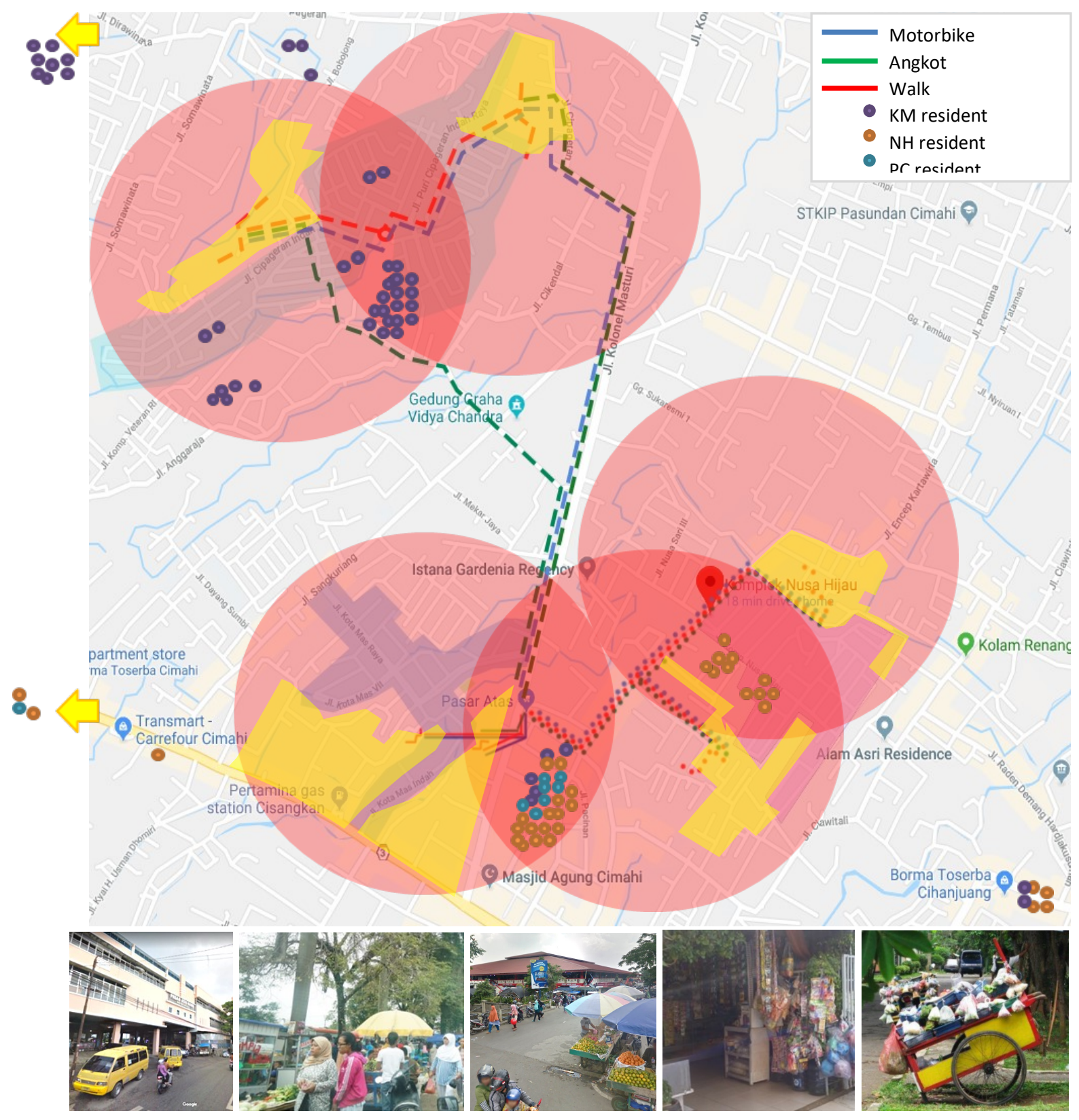

Figure 5 Route and mode of transport to shop

(Bottom left-right: Pasar Atas, Pasar Puri, Pasar Antri, typical warung, mobile greengrocer) 
The patterns of groceries shopping to warung, mobile greengrocer and traditional market are provided in the following quotes. The reason is mostly due to the locations which incur no travel cost.

Pasar Atas, sometimes [I shop there] everyday on foot. The price must be about the same, [I shop there] because it is near (NKM)

Sometimes [I shop] at Pasar atas, sometimes to the mobile greengrocer. Just walk through here [to go to the market], the alleys, very near...at least 6 times a month. I buy rice [at the market] since the mobile greengrocer does not sell rice (DKM)

I buy vegetables daily at the mobile greengrocer...or warung, the nearest one. I shop every day but only a little, only the necessities, spend about 2000 [rupiah]. Let the mobile greengrocer come so I do not need to spend travel cost to go the market. It is budget efficiency, honestly (TRNH)

To go to Pasar Atas which located 600 meters away from their houses, NH kampung dwellers sometimes ride angkot and sometimes walk depends on traffic as well as their mood as the quotes below describe:

Sometimes I ride angkot but sometimes in the morning there is traffic congestion so I walk. It is very congested. I go there [Pasar Atas] every day (NNNH)

If I go to Pasar Atas I ride angkot. If I felt like walking then I like to walk through the NH housing estate, it is nice to stroll. Most of the time [I shop at] warung though (INH)

\subsection{School}

From the total amount of participants, provided in figure 6, nearly half have no school-aged children; either their children are still very young or have become adults. The modes of transportation of these school-aged children are divided almost equally between those who walk, ride angkot, and ride private vehicles (drive themselves or drop by their parents). Looking at where they reside, no contrasting difference can be found between the estate residents and kampung dwellers, for example KM kampung dwellers and $\mathrm{NH}$ estate residents do not ride angkot to school. The school location that both kampung dwellers' and estate residents' children attend to are within reasonable distance in which $5 \mathrm{~km}$ at the furthest.

The patterns on the use of mode of transportation to school are highly varied. It differs due to high variety of factors, such as the age of the children, the angkot route, the parents' schedule, as well as friends who accompany the children. These factors are uttered by the participants in the following quotes:

My eldest child studies at SMP Pasundan 1 di Ciawitali near the city government office. The youngest at SD Mandiri 3 Cipageran at Sawahlega. They go to school with their father. The youngest goes home on foot while the eldest rides angkot. The route started from KM housing estate, to Citeureup, to Police Office. The youngest walk around 10 minutes usually with friends (AKM) 


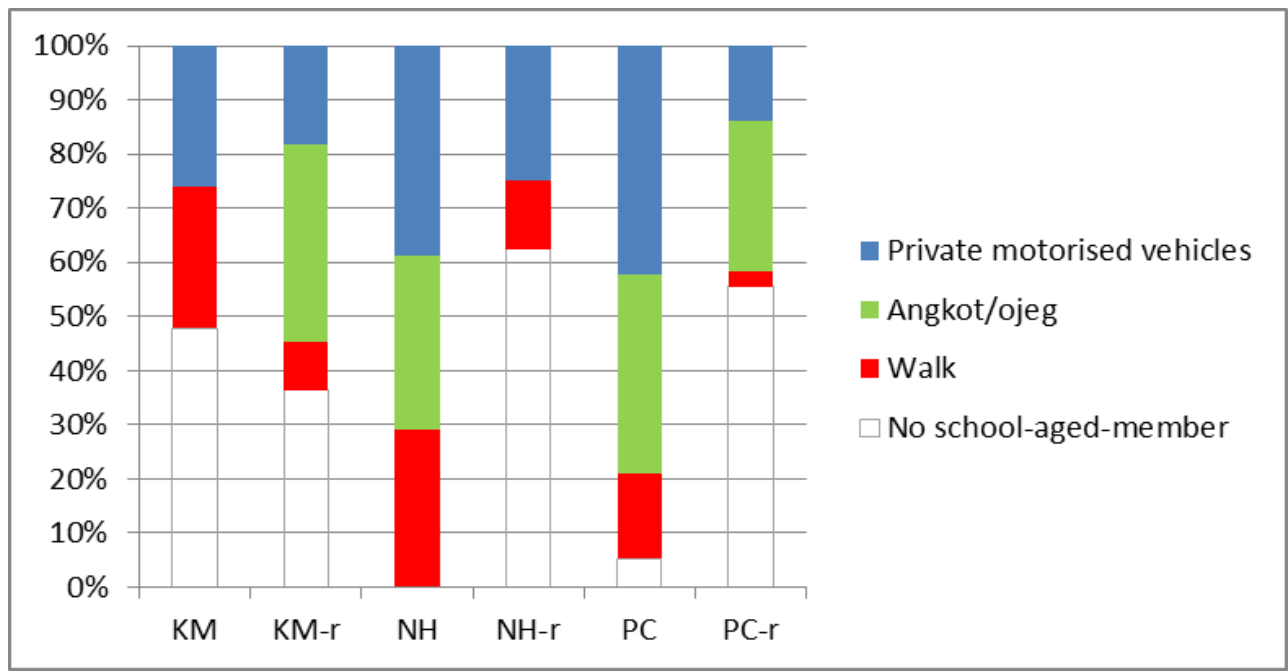

Figure 6 Mode of transportation to school

The shut down of pedestrian access in NH housing estate have affected one of the kampung dwellers. She said that her child has to overcome further distance from previously only 600 meters to become 900 meters. However, they are dealing with it as quoted below:

My eldest studies at SDN Mandiri 5 Cimahi. Walk [to school] not too far through Sudarman alley. Previously [before the pedestrian gate was shut] was nearer. We though about moving to a new school, but he is now at the 4th grade so only two years left [until graduation] (ASNH)

Different to the two other locations, participants at PC housing estate and kampung dwellers who ride angkot, ojeg or private vehicles are much more than those who walk. The routes shown in figure 7 show that the schools are located outside the walking distance. The following quotes describe:

The eldest child now studies at UNISBA and rides motorbike there. He used to study at SMA 3 Cimahi, SMP 3 Cimahi, and SD Cimahi 1. He rides motorbikes since the final year of junior high school (SMP). Before that, his father drops him off the motorbike (ISPC)

My eldest studies at SMK 3, Cipageran and the youngest at SDN Mandiri 1 at the $5^{\text {th }}$ grade. The eldest usually rides Grab, the youngest rides angkot (LIPC) 


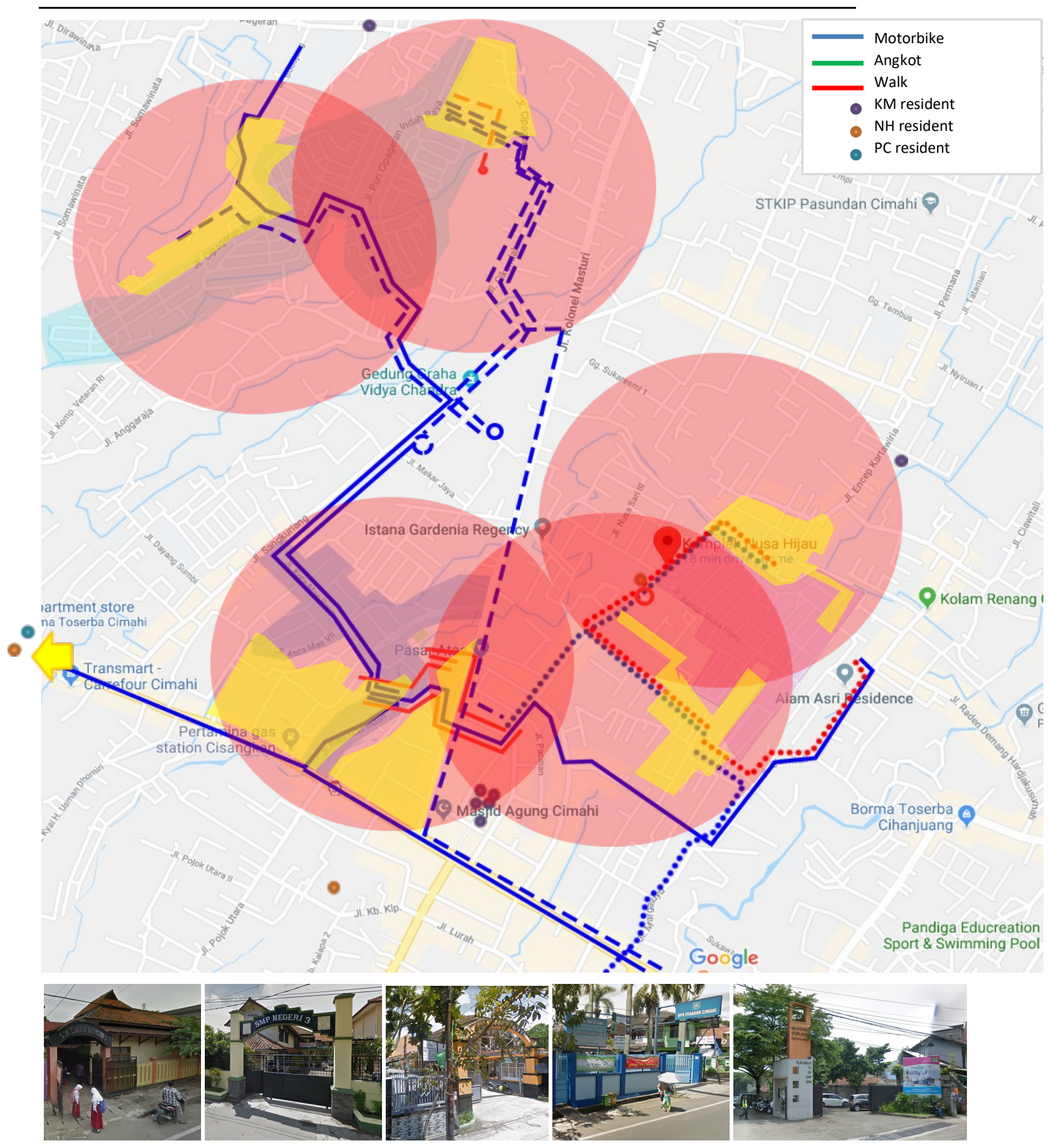

Figure 7 Route and mode of transportation to school

(Bottom left-right: public primary schools [SDN, SMP, SMK], private schools) 


\subsection{Exercise}

For exercise activities, the top graph in figure 8 shows that around 30per cent of participants exercise at home or do not exercise. Meanwhile, 50 per cent walk as a form of exercise as well as to reach the destination to do an exercise. Only a small percentage of participants ride private vehicles or angkot since they travel between 3 to $5 \mathrm{~km}$. Looking at where they reside, no contrasting difference on travel mode can be found between the estate residents and kampung dwellers.

The bottom graph in the same figure shows the destination of exercise at each case. In KM, the estate residents exercise by walking around the area. While most kampung dwellers exercise at Sangkuriang stadium located just on the other side of KM housing estate, some of them exercise at Brigif ( $5 \mathrm{~km}$ away) and Kenfer swimming pool ( $3 \mathrm{~km}$ away), and only a few exercise at KM housing estate. Similar to estate residents in KM, most estate residents in $\mathrm{NH}$ and PC exercise by walking around the area and the rest exercise at Brigif. The kampung dwellers in NH and PC exercise at various locations: Most NH kampung dwellers exercise at several locations within $1 \mathrm{~km}$ radius and a small portion exercise at Brigif and the $\mathrm{NH}$ housing estate; Most PC kampung dwellers exercise at the neighbourhood field, 10 per cent exercise at PC housing estate, 5 per cent at Kenfer swimming pool ( $3 \mathrm{~km}$ away), and the last 5 per cent at a nearby sport stadium.

The variety of exercise locations of the kampung dwellers are caused by several factors such as shopping, availability of instructor, and accompany. These factors are mentioned in the following quotes:

[I exercise at] Sangkuriang or Brigif stadium. I exercise at Sangkuriang stadium because it is closer [than Brigif] and it has a market (pasar tumpah) as well. I go there through $\mathrm{KM}$. If I go to Brigif I like to ride motorbike, much more to see there. Exercise while shopping (DKM)

[Sometimes I do gymnastics (senam)] at RSGM (dental hospital) every Tuesday and Sunday. Usually I go to Permana...by riding angkot twice a week. An instructor is provided there (RNNH)

We like to do gymnastics (senam) in the rear of Ramayana [near the old townhall] every Sunday morning. I walk there with fellows [who live] here (ibu-ibu disini). We never ride angkot since the route would be further (jauh muter-muter). It is better to walk, not far through shortcuts (LNH)

At the old townhall we do Zumba every Sunday. At KM we exercise at 6 AM, then we continue at the old townhall at 8 AM. We walk [because] it is near (SKM). 


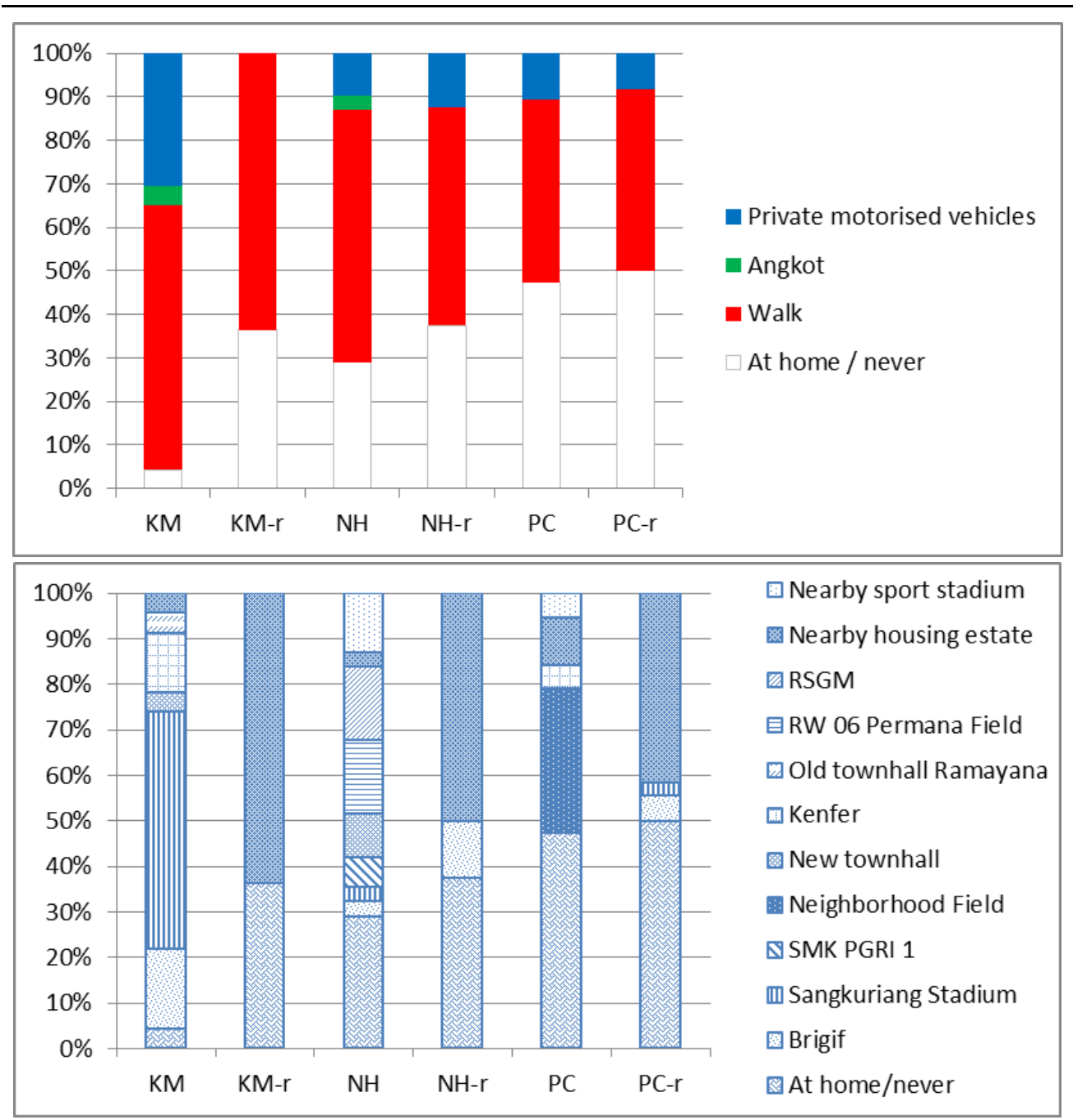

Figure 8 Mode of transportation and destination for exercise activities (Top-bottom: Mode of transportation, exercise destination)

For the NH kampung dwellers, some of them used to exercise at a park in NH housing estate. However, they no longer do so since the shut down of pedestrian gate as quoted below:

I also used to like to do gymnastics (senam) there [at a park in $\mathrm{NH}$ ]. After that [the shut down of pedestrian gate] I walk [as an exercise] to Ciuyah all the way to Kamarung since I have a friend who used to be a neighbour live there. I almost never exercise [at $\mathrm{NH}$ ] anymore. I had once exercised there by riding a motorbike but then never again (SRNH). 


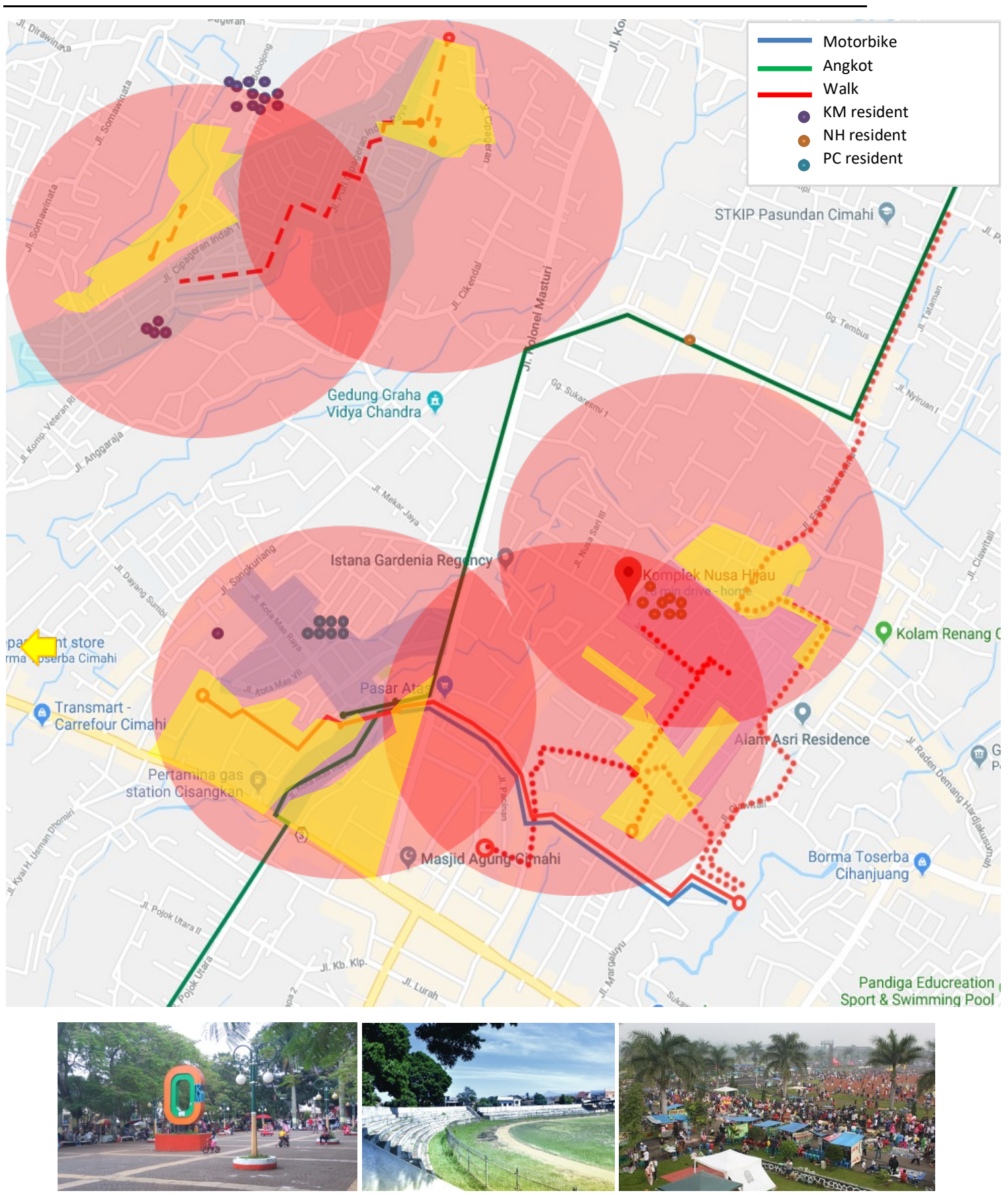

Figure 9 Route and mode of transportation to school

\subsection{Discussions}

To understand the phenomenon of how the middle-income housing and their gated community has impacted travel pattern, this paper tries to explore the extent of automobile dependency of the residents living at housing estate and the dwellers living at adjacent kampung. The journey to four kinds of activities can be grouped into the following patterns. 
Majority of participants drive their private motorised vehicles to work which located at a various distance from $5 \mathrm{~km}$ to $30 \mathrm{~km}$. Only a small percentage of participants who live in the kampung walk or ride angkot as the public transportation to work. None of the estate residents walk or ride angkot to work. For groceries shopping activities, the majority of participants walk. However, there is a notable difference where the kampung dwellers mostly walk or ride angkot to buy groceries while the housing estate residents are divided between walk and riding their vehicles. The children, both living at the housing estate and kampung, go to school by walking, riding angkot, and riding private vehicles (drive themselves or drop by their parents). For exercise, no contrasting difference on travel mode can be found between the estate residents and kampung dwellers. Fifty per cent walk as a form of exercise as well as to reach the destination to do an exercise. Only a small percentage of participants ride private vehicles or angkot since they travel between 3 and 5 $\mathrm{km}$ to do the exercise.

Most residents travel in far distance to reach their job location but do not travel in far distance to conduct their shopping, studying, and exercise activities though some of them own a motorbike. The latter is due to the presence of mobile green grocers, warung, traditional markets, good quality schools, sport facilities and open spaces within walking distance to their houses. However, these facilities are visited mostly because there are pedestrian access points through the housing estates made available for public use.

When these access points are restricted or non-existed, the travel pattern would differ as has been uttered by the kampung dwellers. A number of participants have mentioned that travelling to work, grocery shopping, school, and exercise has been made easier owing to the pedestrian access points. In one of the cases, the following disconnections between the kampung alleys and streets of housing estates have made the kampung dwellers altered either the location or the transportation mode of their exercise activities. The weaving of a network comprised of kampung alleys and private roads of housing estate has proven to be beneficial for the kampung dwellers. In several examples, such as in shopping and exercise activities, it has also changed them from riding a motorbike to walking. It has showcased the impact on creating a healthier and more affordable travel behaviour.

Owing to this pedestrian access, kampung alleys become connected to the streets within the housing estates and create shortcuts for pedestrian to walk through. Such network is a privilege for the pedestrian, since they cannot be accessed by cars and in some parts difficult to be accessed by motorbikes due to the narrow alleys.

\section{Conclusions}

There are lessons to be learned from these travel patterns. Housing estate development shall always provide access to the kampung that have existed and vice versa. Such spatial connections will promote a change of travel behaviour from automobile dependence to active travel. However, it should be kept in mind that these results may not be generally applicable to other places with different socio-economic and spatial characters. Acknowledging the large amount of gated communities in Indonesia, further work in the field may be benefited from more cases and larger population sample. 


\section{References}

Barter, P.A (2000) "Urban transport in Asia: Problems and prospects for high-density cities", Asia-Pacific Development Monitor, Vol. 2 No 1, pp.33-66.

Bowen, J (2006) Tigers in a traffic jam: Urban transport in Southeast Asia. In: Wong, T., Shaw, B. \& Goh, K. (Eds.). Challenging sustainability: Urban development and change in Southeast Asia. Marshall Cavendish Academic, pp. 108-145.

BPS (2018) Indonesia in figures. Jakarta: Badan Pusat Statistik.

Cervero, R. \& Kockelman, K (1997) "Travel demand and the 3Ds: Density, diversity, and design", Transportation Research D, Vol. 2 No 3, pp. 199-219.

Charmes, E (2010) "Cul-de-sacs, superblocks and environmental areas as supports of residential territorialisation", Journal of Urban Design, Vol. 15 No 3, pp. 357-374.

Duany, A., Plater-Zyberk, E. \& Speck, J (2000) Suburban nation: The rise of sprawl and the decline of the American dream, New York: North Point Press.

Ewing, R. \& Cervero, R (2010) "Travel and the built environment: A meta-analysis", Journal of the American Planning Association", Vol. 76 No 3, pp. 265-94.

Grant, J. \& Curran, A (2007) "Privatized suburbia: The planning implications of private roads", Environment and Planning B: Planning and Design, Vol. 34 No 4, pp. 740754.

Handy, S (2002) Accessibility vs mobility-enhancing strategies for addressing automobile dependence in the US. European Conference of Ministers of Transport.

Hess, P., Moudon, A., Snyder, M. \& Stanilov, K (1999) "Site design and pedestrian travel", Transportation Research Record: Journal of the Transportation Research Board, No 1674, pp. 9-19.

Hoehner, C., Ramirez, L., Elliott, M., Handy, S. \& Browson, R (2005) “Perceived and objective environmental measures and physical activity among urban adults", American Journal of Preventive Medicine, Vol. 28 No 2, pp. 105-116.

Khattak, A. \& Rodriguez, D (2005) "Travel behaviour in neo-traditional neighbourhood developments: A case study in USA“, Transportation Research Part A, Vol. 39, pp. 481-500.

Maher, C (1994) "Residential Mobility, Locational Disadvantage and Spatial Inequality in Australian Cities", Urban Policy and Research, Vol.12, pp. 185-191.

Mateo-Babiano, I; leda, H (2007) "Street space sustainability in Asia: The role of the Asian pedestrian and street culture", Journal of the Easterns Asia Society for Transportation Studies, Vol. 7, pp. 1915-1930.

Newman, P. \& Kenworthy, J (1996) "The land use-transport connection: An overview", Land use Policy, Vol. 13 No 1, pp. 1-22.

Newman, P. \& Kenworthy, J (1999) Sustainability and cities: Overcoming automobile dependence. Island Press. 
Nicholls, L., Phelan, K. \& Maller, C (2015) "Time poor, health poor? Travel-related time poverty and resident health in a greenfield master-planned estate", State of Australian Cities Conference 2015.

Rodriguez, D. A., Khattak, A. J., \& Evenson, K. R (2006) “Can new urbanism encourage physical activity? Comparing a new urbanist neighborhood with conventional suburbs", Journal of the American Planning Association, Vol.72 No 1, pp. 43-54.

Rosa, J (2007) A step towards sustainable transportation behaviour: Understanding automobile ownership and mode choice through qualitative research, Master thesis, Waterloo:, University of Waterloo,.

Schwanen, T. \& Mokhtarian, P (2005) "What if you live in the wrong neighbourhood? The impact of residential neighbourhood type dissonance on distance traveled", Transportation Research Part D, Vol. 10, pp.127-151.

Southworth, M (2005) "Designing the walkable city", Journal of Urban Planning and Development, Vol. 131 No. 4, pp. 246-257.

https://www.tomtom.com/en gb/traffic-index/jakarta-traffic\#statistics

http://inrix.com/scorecard/ 